\title{
Research Article \\ Effects of Climate and Land Use Changes on Water Resources in the Taoer River
}

\author{
Jianwei Liu,, ${ }^{1}$ Can Zhang, ${ }^{1}$ Limin Kou, ${ }^{2}$ and Qiang Zhou ${ }^{1}$ \\ ${ }^{1}$ School of Hydraulic Engineering, Dalian University of Technology, Dalian 116024, China \\ ${ }^{2}$ Institute of Urban Environment, Chinese Academy of Sciences, Xiamen 361021, China \\ Correspondence should be addressed to Jianwei Liu; jwliu@dlut.edu.cn
}

Received 8 December 2016; Revised 10 February 2017; Accepted 23 February 2017; Published 23 March 2017

Academic Editor: Francesco Viola

Copyright (C) 2017 Jianwei Liu et al. This is an open access article distributed under the Creative Commons Attribution License, which permits unrestricted use, distribution, and reproduction in any medium, provided the original work is properly cited.

The changes of both climate and land use/cover have some impacts on water resources. In the Taoer River basin, these changes have directly influenced the land use pattern adjustment, wetland protection, connections between rivers and reservoirs, local social and economic development, and so forth. Therefore, studying the impacts of climate and land use/cover changes is of great practical significance. The Soil and Water Assessment Tool (SWAT) model is employed in this study. With historical measured runoff data and remote sensing maps of annual land use classifications, we analyzed the impacts of climate change on the runoff of the Taoer River. Based on the land use/cover classifications of 1990, 2000, and 2010, we analyzed the land use/cover change over the last 30 years and the contribution coefficient of farmland, woodland, grassland, and other major land use types to the runoff. This study can provide a reference for the rational allocation of water resources and the adjustment of land use structure for decision makers.

\section{Introduction}

Currently, climate change is a global problem. Climate change intensifies the global hydrological cycle [1]. The fifth climate change assessment report $[2,3]$ of the United Nations Intergovernmental Panel on Climate Change (IPCC, the Intergovernmental Panel on Climate Change) noted that, with the increasing cumulative greenhouse gas $\left(\mathrm{CO}_{2}\right.$, etc. $)$ emissions, the average global-surface temperature has been increased during the twenty-first century. Northeast China is located in the high latitudes of the Northern Hemisphere and the eastern end of Eurasia, and this region has shown high sensitivity to global climate change since the 1950s. Statistics from the meteorological department of China show that the phenomenon of rising temperature in this area is markedly greater than the national average [4]. Rising temperatures will accelerate the hydrological cycle through enhanced evaporation. Additionally, the intensity, frequency, and spatial distribution of precipitation will change $[5,6]$. Rising temperature has a significant impact on water resources in a river basin [7]. Northeast China is an important commodity grain base, and it is a crucial component of China's food safety system and agricultural production. Since agricultural water consumption covers approximately $70 \%$ of the total water consumption in this area, climate change will also indirectly affect agricultural production [8].

Land use/cover change (LUCC) seriously affects water resources $[9,10]$. As the most direct expression of the interaction between human activities and the natural environment, land use/cover change is the interaction that links human activities and natural ecological processes [11]. Land use/cover changes directly affect the condition of water resources and agricultural economic growth. In recent years, frequent human activities, for example, deforestation, afforestation, and farmland reclamation, have led to significant agricultural-land-pattern changes (Henze, 1977; McCann, 1995). Land use/cover changes affect water resources mainly through vegetation interception, evapotranspiration, runoff, surface infiltration, soil moisture status, and so forth, thereby affecting the process of watershed hydrology and water resource cycles [12-14] (Shi Xiaoliang et al., 2014). In addition, the rising temperature in Northeast China has led to an annual accumulated increase, which provides favorable climatic conditions for forests and 

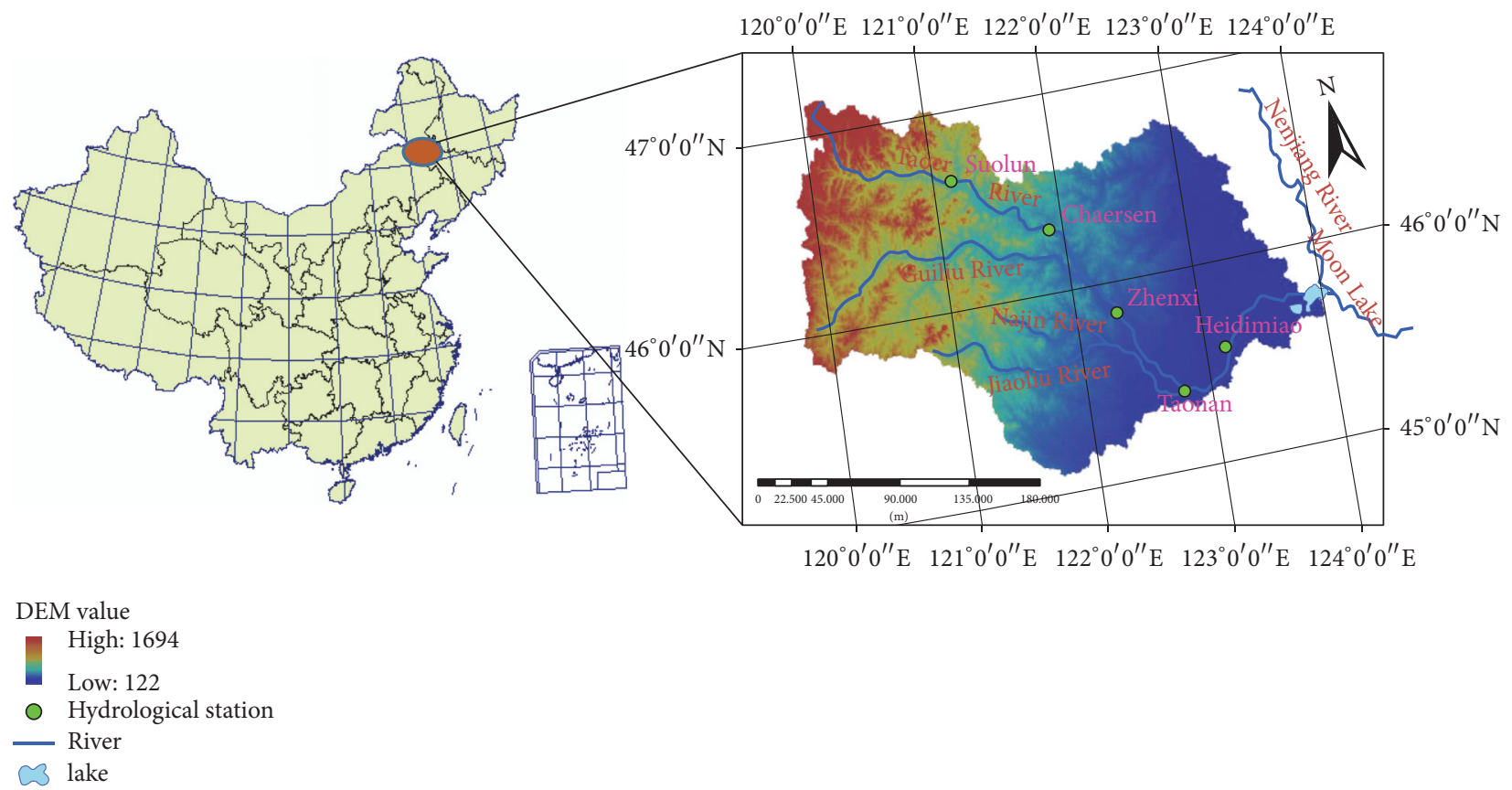

FIgURE 1: Water system diagram of the Taoer River basin.

grasslands reclaimed in the large arid regions [11]. In this way, climate change, water resource conditions, and land use/cover changes influence one another.

Both climate change and land use/cover change have an impact on water resources. Therefore, the study of the impacts of climate change and land use/cover change on stream flow within a river basin has become an important topic in hydrology and water resource fields. There are many scholars that have conducted studies on this topic [15-18]. Currently, the most widely used method is the application of a hydrological model to quantify and assess hydrological conditions (Xu zongxue et al., 2010) [10]. The SWAT model has been demonstrated to be an effective tool for researching the impact of environmental changes on hydrology and water resources. Many scholars [19-23] used the SWAT model to analyze the response of the hydrological cycle under the climate change and land use/cover change. Also some [2426] evaluated the impacts of increased atmospheric $\mathrm{CO}_{2}$ concentration and other potential climate change elements on the water cycle. Some [26-28] also used SWAT to study the effects of climate change and land use/cover change on agriculture.

In this paper, the Taoer River basin was introduced as a case study. The data for the basin, including elevation, hydrology, slope, land use, soil type, and land coverage, were obtained by using RS and GIS technology. The SWAT model was employed to assess the effects of three main land use types (arable land, woodland, and grassland) on water resources considering climate change and land use/cover change processes in the Taoer River basin. The contribution coefficients [29] of the three land use types to the runoff depth were calculated. The results can help water conservancy administrative departments in land use planning and water resource management.

\section{Study Area}

The Taoer River is the largest tributary of the Nenjiang River (Figure 1). It originates in Horqin Right-Front-Country. Its stream length is $563 \mathrm{~km}$, with a drainage area of $4.18 \times 10^{4} \mathrm{~km}^{2}$ $[30,31]$. The Taoer River basin (TRB) terrain gradually rises from the southeast to the northwest; the upper reaches pass through the mountains of the Inner Mongolia Autonomous Region. The stream gradient is approximately $16.6 \%$, while in the downstream area from Zhenxi to the plains, the stream gradient is approximately $0.2 \%$. The TRB is located in a semiarid area with a temperate continental monsoon climate. The climate is cold, dry, and rainless in winter due to the Mongolia high-pressure system, whereas the climate is hot and rainy in summer due to the West Pacific subtropical highpressure system. The precipitation, temperature, evaporation, and runoff vary greatly at interannual and intra-annual timescales. The mean air temperature is between -2.5 and $5^{\circ} \mathrm{C}$ (decreasing from north and south), with a mean annual precipitation of $430-900 \mathrm{~mm}$ (decreasing from southeast to northwest), potential evapotranspiration of $800-1,900 \mathrm{~mm}$ (decreasing from southeast to northwest), and annual average natural runoff in the TRB of $1600 \mathrm{~km}^{3}$ (i.e., from 1956 to 2000).

The upper mountainous area of the TRB, which is covered with forest and grassland, is the key area of runoff yield. The middle and downstream plain areas, which are covered with grassland and arable land, are an important part of the northeast commercial grain bases. The vegetation types and coverage of the entire basin in 1990, 2000, and 2010 are shown in Figure 2. Analysis of the main land cover type changes over the past 20 years shows that the arable land area increased by $13.94 \%$, whereas woodland decreased by $13.14 \%$, 


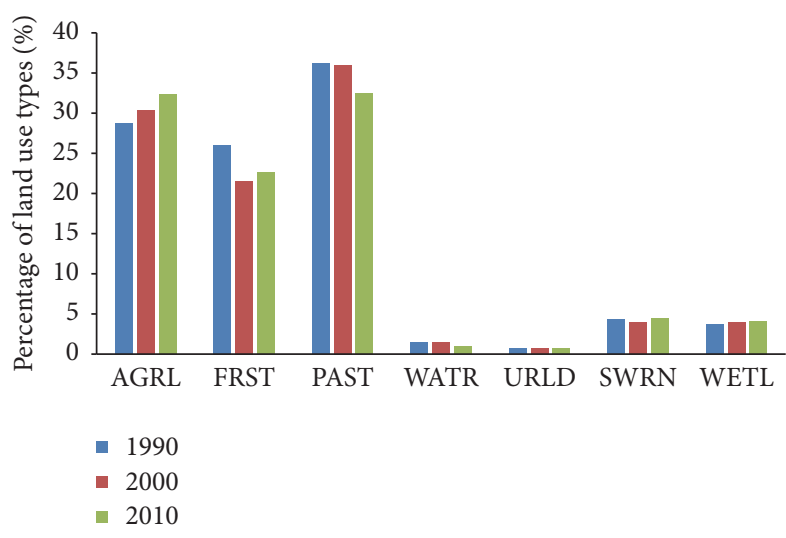

Figure 2: Taoer River basin land use.

and grassland decreased by $10.23 \%$. In addition, farmland, woodland, and grassland are the major land use types in the TRB, accounting for approximately $90 \%$ of the entire basin, followed by unused land and marshes, whereas the share of water and settlements account for a smaller proportion.

\section{Applied Methodologies}

3.1. Model Selection. To research on the impact of climate change and land use/cover change on hydrology and water resources, hydrological modeling techniques are currently the most widely used, and these methods can be mainly divided into three categories: statistical models, conceptual hydrological models, and distributed hydrological models. Experience statistical models are based on the relationship among the statistical data of runoff, rainfall, and air temperature. The disadvantage of these models is that, for long time series of data, the pure statistical model has some limitations in terms of projecting future water resources. Conceptual hydrological models, such as the Stanford model, the Tank model, and the Xin Anjiang model, are based on hydrological phenomena in the relationship of climate and runoff. The disadvantage of these models is that the river basin is assumed to be integral component, which neglects the spatial heterogeneity caused by the differences of topography, vegetation, and soil.

Distributed hydrological models, such as the SWAT model, TOPMODEL model, and VIC models, are large-scale basin models that have been widely used recently [32-34]. As a typical distributed hydrological model, the SWAT model is globally used because the input variables can be easily obtained, it has high computational efficiency, it provides long-term watershed simulation, and it is open sourced. It can be modified based on the actual characteristics. By 2012, more than 1,000 peer-reviewed articles have been published that document its various applications $[35,36]$.

3.2. Method. In this paper, we use historical runoff data and previous studies on climate to analyze the impact of climate change on runoff in the Tao River. We also analyzed the cover change and its influence on runoff in Taoer River basin, on the basis of the land use classification data in different years from satellite remote sensing images. Then we analyze main types of land use change and runoff depth contribution coefficient, such as farmland, woodland, and grassland. This study provides a reference for the rational allocation of water resources and the adjustment of land use structure.

In order to calculate the contribution coefficient of runoff depth on the main land use types in the Taoer River basin, multiobjective decision-making method is used $[29,37,38]$. The multiobjective decision-making method is a method of decision analysis, developed in the mid-1970s. Multiobjective decision-making generally includes multiobjective decision making and multiattribute decision making. It has a wide range of applications. At present, it has achieved rapid development in theory, method, and application.

When the multiobjective decision-making method is used to calculate the contribution coefficient of runoff depth, the basic objective function can be expressed by the annual average runoff depth formula, as shown in formula (1):

$$
R_{X}=V_{a} \times A_{x}+V_{f} \times F_{x}+V_{p} \times P_{x}+V_{u} \times U_{x}+\cdots,
$$

where $V_{a}, V_{f}, V_{p}, V_{u}, \ldots$ represent the contribution coefficient of runoff depth in cultivated land $\left(A_{x}\right)$, woodland $\left(F_{x}\right)$, grassland $\left(P_{x}\right)$, and construction land $\left(U_{x}\right)$ in each unit area $\left(\mathrm{km}^{2}\right)$, respectively. The units are $\mathrm{mm} \cdot \mathrm{km}^{-2} \cdot X$ is the land use scenario among different years, for example, 1990, 2000, and 2010.

Transforming formula (1) can obtain formula (2):

$$
\begin{aligned}
{\left[\begin{array}{l}
R_{2}-R_{1} \\
R_{3}-R_{2} \\
R_{1}-R_{3}
\end{array}\right]=} & {\left[\begin{array}{lll}
A_{2}-A_{1} & F_{2}-F_{1} & W_{2}-W_{1} \\
A_{3}-A_{2} & F_{3}-F_{2} & W_{3}-W_{2} \\
A_{1}-A_{3} & F_{1}-F_{3} & W_{1}-W_{3}
\end{array}\right] } \\
& \times\left[\begin{array}{l}
V_{1} \\
V_{2} \\
V_{3}
\end{array}\right] .
\end{aligned}
$$

Different subscripts represent different years.

After the establishment of the multiobjective decisionmaking function, the function is solved by MATLAB, and we can obtain the runoff depth contribution coefficient of different land use types.

3.3. Data Sources. To set up the SWAT model, the input data required include DEM (Digital Elevation), land use/cover, soil type, and hydrometeorology.

The DEM data (SRTM90m) were obtained from the Chinese Academy of Sciences Computer Network Information Center and the international scientific data mirror sites (http:// www.gscloud.cn/). Because the middle and lower reaches of the basin are located in the plains, there will be a larger error when using DEM to extract the river catchment. "Burn in" was applied as a corrective technique by importing a drainage map to extract the river catchment. The 1:4,000,000 electronic water system diagram was obtained from the National Fundamental Geographic Center (http://ngcc.sbsm.gov.cn).

Land use data were obtained from the "Western China Environment and Ecological Science Data Center" (http://westdc.westgis.ac.cn) of the National Natural Science Foundation. The original land use/cover types of the 

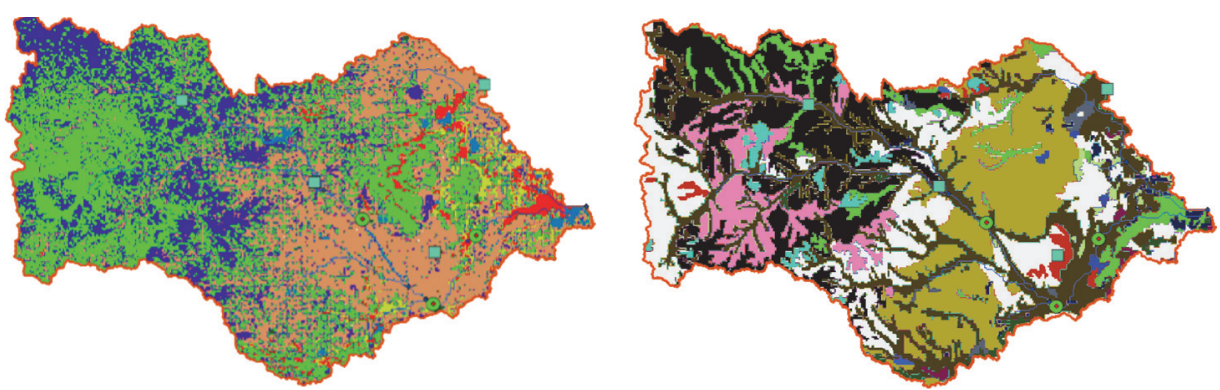

$\begin{array}{ll}\square \text { AGRL } & \square \text { URHD } \\ \square \text { FRST } & \text { URLD } \\ \square \text { PAST } & \square \text { UIDU } \\ \text { WATR } & \text { WETL }\end{array}$

(a)

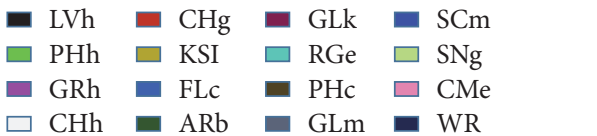

(b)

FIgURE 3: (a) Vegetation types and (b) soil types in the Taoer River basin.

data classification method adopted six categories of 25 subcategories. To make the land use types of the study area the same as the land use parameter library, the original ones were reclassified; the code of each type was the same as the standard code of the SWAT model. The classification scheme is shown in Figure 3(a).

Soil data were obtained from the "Black River Planning Data Management Center" (http://westdc.westgis.ac.cn). The original soil data were reclassified by ArcGIS. The various types of soil were converted into those codes that can be identified by the SWAT model. The soil classification scheme is shown in Figure 3(b).

Hydrological and meteorological data were obtained from the China Basin Meteorological Data Sharing Service Network (http://data.cma.cn) and hydrological stations in the Taoer river basin, including the Aershan, Ulanhot, Solon, Baicheng, and Tailai weather stations. The meteorological parameters included daily precipitation, maximum and minimum temperature, relative humidity, wind speed, and solar radiation. Data were also obtained from the Solon, Chersen, Taonan, and Zhenxi hydrological stations. The geographical locations are shown in Figure 1.

3.4. Simulation. According to the Taoer River Drainage Network, the Solon, Charlson, Zhenxi, and Taonan hydrological stations were selected as subbasin outlets, and the entire river basin was divided into 27 subbasins (Figure 4). On the basis of the subbasin, land use data and a soil type map were input into the SWAT model, with a set basin slope rating. Combined with actual observations of the Taoer River basin, land use, soil type, and slope of the threshold values were set at $10 \%$, and the Taoer River was divided into 1,663 hydrological response units (HRUs). After meteorological data and other database files were input to the model, the watershed hydrological simulation process was achieved.

3.5. Parameter Sensitivity Analysis. SWAT-CUP was developed by the Swiss Federal Institute of Water Science and Technology (EAWAG), which specializes in SWAT calibration, validation, and uncertainty analysis. They integrated the continuous uncertainty matching algorithm (SUFI-2), particle swarm optimization (PSO), generalized likelihood uncertainty algorithm (GULE), parameter Solution (ParaSol), Markov Chain Monte Carlo (MCMC), and many other programs. The parameter sensitivity analysis, calibration, verification, and uncertainty analysis can be performed by comparing the results of the SWAT model to those of the SWAT-CUP [39]. Based on the SWAT-CUP program, the SUFI-2 algorithm (Sequential Uncertainty Fitting algorithm) [40] was chosen for the sensitivity analysis of the model parameters.

Snowmelt, runoff confluence, evapotranspiration, and subsurface flow are the main hydrological processes involved in SWAT model simulation (Xia Jun et al., 2003; Liu Changming et al., 2004; Wang Zhonggen et al., 2004). Many parameters may impact the simulation; some of the less sensitive parameters can be removed through the model parameter sensitivity analysis to improve the efficiency of the model calibration. Based on the actual situation of the Taoer River basin, 19 parameters were chosen, and the calibrated values of parameters are shown in Table 1 . The sensitivity analysis results are shown in Tables $2-5$ (top ten sensitivity parameters).

3.6. Model Simulation and Verification. Hydrometeorological data from 1988-1989 were used to pretest the model, data from 1990-1993 years were used for model calibration, and data from 1994-1996 were used for model validation. In this paper, the Nash-Sutcliffe efficiency coefficient $E_{\mathrm{NS}}$, the correlation coefficient $R^{2}$, and the relative error RE were used to evaluate the adaptation degree between the SWAT model simulation results and the measured values. The computational formulas of $E_{\mathrm{NS}}, R^{2}$ and $\mathrm{RE}$ are as follows:

$$
\begin{aligned}
E_{\mathrm{NS}} & =1-\frac{\sum_{i=1}^{n}\left(Q_{m i}-Q_{s i}\right)^{2}}{\sum_{i=1}^{n}\left(Q_{m i}-\overline{Q_{m}}\right)^{2}}, \\
R^{2} & =\frac{\sum_{i=1}^{n}\left[\left(Q_{m i}-\overline{Q_{m}}\right)\left(Q_{s i}-\overline{Q_{s}}\right)\right]^{2}}{\sum_{i=1}^{n}\left(Q_{m i}-\overline{Q_{m}}\right)^{2} \sum_{i=1}^{n}\left(Q_{s i}-\overline{Q_{s}}\right)^{2}},
\end{aligned}
$$


TABLE 1: Calibrated parameter values for the Taoer River basin.

\begin{tabular}{lcccc}
\hline Parameter & Influence object & Minimum value & Maximum value & Fitted Value \\
\hline CN2 & Surface runoff & -0.2 & 0.2 & -0.11 \\
SURLAG & Surface runoff & 1 & 24 & 16.52 \\
ALPHA_BF & Groundwater & 0 & 1 & 0.38 \\
GW_DELAY & Groundwater process & 30 & 450 & 25.99 \\
GW_REVAP & Groundwater process & 0 & 0.2 & 0.20 \\
ESCO & Soil evaporation & 0.8 & 1 & 0.97 \\
CH_N2 & River confluence & 0 & 0.3 & 0.03 \\
CH_K2 & River confluence & 5 & 130 & 175.93 \\
ALPHA_BNK & Stream runoff & 0 & 1 & 0.75 \\
GWQMN & Soil moisture & 0 & 2 & 0.88 \\
SOL_AWC(1) & Soil moisture & -0.2 & 0.4 & 0.36 \\
SOL_K(1) & Soil moisture & -0.8 & 0.8 & -0.34 \\
SOL_BD(1) & Soil moisture & -0.5 & 0.6 & 0.51 \\
SFTMP & Snowfall and snow melting & -5 & 5 & 4.47 \\
SMFMX & Snowfall and snow melting & 0 & 10 & 7.41 \\
SMFMN & Snowfall and snow melting & 0 & 10 & 4.11 \\
SMTMP & Snowfall and snow melting & -5 & 5 & 0.33 \\
TIMP & Snowfall and snow melting & 0.01 & 1 & 0.35 \\
\hline
\end{tabular}

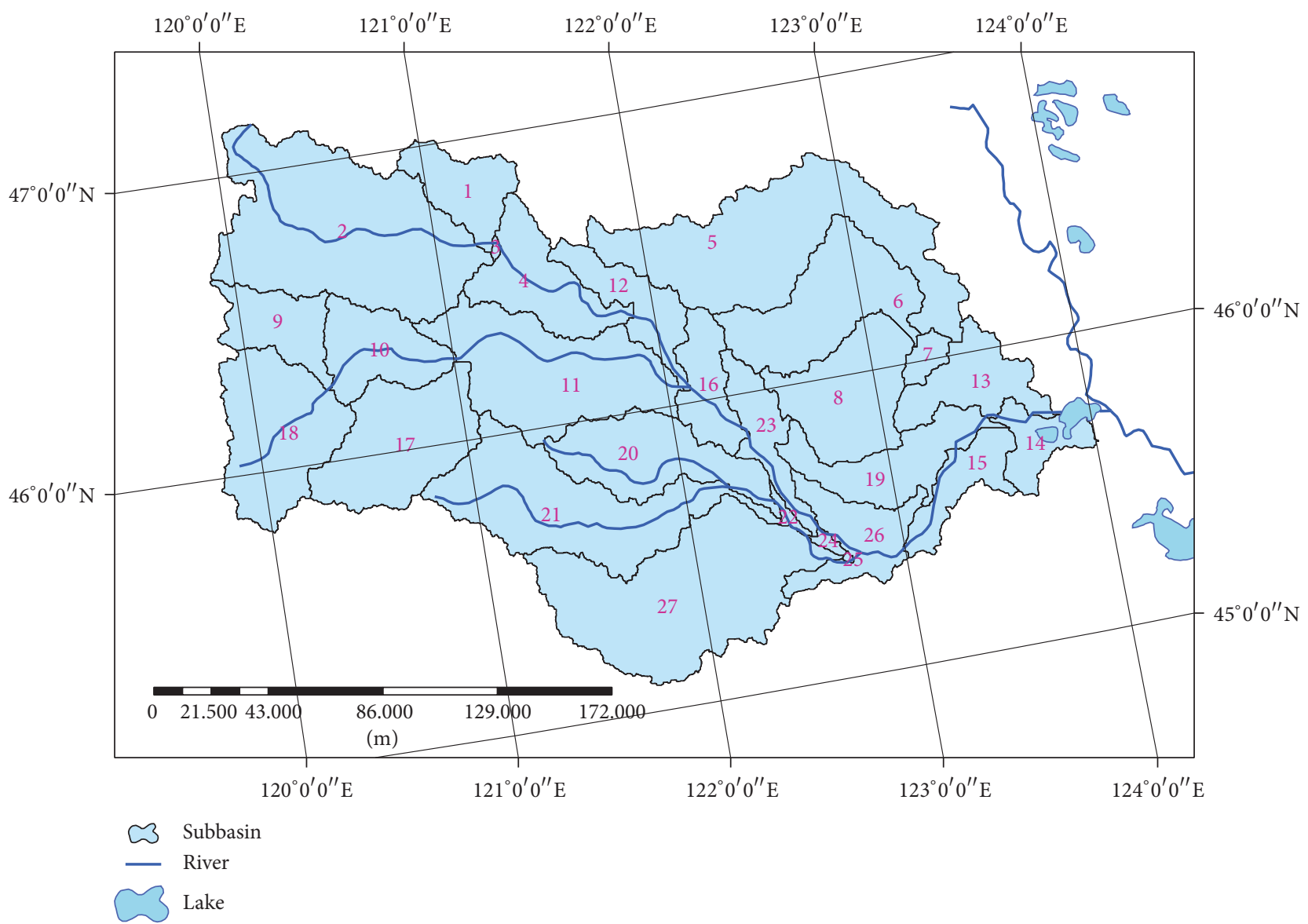

FIGURE 4: Subdivisions of the watershed. 
TABLE 2: The sensitivity analysis results of the Suolun hydrological station.

\begin{tabular}{lccc}
\hline Sensitivity ranking & Parameter of SWAT & Influence object & Sensitivity \\
\hline 1 & GW_DELAY & Groundwater process & Surface runoff \\
2 & CN2 & Snowfall and snowmelt & -2.36 \\
3 & SMFMX & Groundwater & 2.28 \\
4 & ALPHA_BF & Soil moisture & 2.08 \\
5 & SOL_BD(1) & Surface runoff & -2.07 \\
6 & SURLAG & Snowfall and snowmelt & -1.76 \\
7 & SMFMN & Groundwater process & -1.74 \\
8 & GW_REVAP & River bank runoff producing & -1.51 \\
9 & ALPHA_BNK & Channel concentration & 0.92 \\
10 & CH_K2 & & -0.66 \\
\hline
\end{tabular}

TABLE 3: The sensitivity analysis results of the Chaersen hydrological station.

\begin{tabular}{lccc}
\hline Sensitivity ranking & Parameter of SWAT & Influence object & Sensitivity \\
\hline 1 & GW_DELAY & Groundwater process & 24.68 \\
2 & SMFMX & Soil moisture & -1.59 \\
3 & ALPHA_BF & Snowfall and snow melting & -1.44 \\
4 & ESCO & Groundwater & -1.26 \\
5 & ALPHA_BNK & Surface runoff & -1.19 \\
6 & CH_K2 & Surface runoff & 1.14 \\
7 & CH_N2 & Snowfall and snow melting & 1.03 \\
8 & SOL_K(1) & Groundwater process & 0.84 \\
9 & GW_REVAP & Stream runoff & 0.77 \\
10 & SMTMP & River confluence & 0.69 \\
\hline
\end{tabular}

TABLE 4: The sensitivity analysis results of Zhenxi hydrological station.

\begin{tabular}{lccc}
\hline Sensitivity ranking & Parameter of SWAT & Influence object & Sensitivity \\
\hline 1 & ALPHA_BF & Groundwater & -23.51 \\
2 & CH_N2 & River confluence & 2.02 \\
3 & SOL_BD(1) & Soil moisture & -1.89 \\
4 & TIMP & Snowfall and snow melting & -1.43 \\
5 & SMFMX & Snowfall and snow melting & 0.98 \\
6 & GW_DELAY & Groundwater process & 0.97 \\
7 & GW_REVAP & Groundwater process & -0.85 \\
8 & SMFMN & Snowfall and snow melting & -0.81 \\
9 & CH_K2 & River confluence & 0.74 \\
10 & ALPHA_BNK & Stream runoff &
\end{tabular}

TABLE 5: The sensitivity analysis results of the Taonan hydrological station.

\begin{tabular}{lccc}
\hline Sensitivity ranking & Parameter of SWAT & Influence object & Sensitivity \\
\hline 1 & ALPHA_BNK & Groundwater & 10.14 \\
2 & CN2 & Surface runoff & -9.28 \\
3 & SFTMP & Snowfall and snowmelt & 2.54 \\
4 & ESCO & Soil water evaporation & 2.18 \\
5 & GW_DELAY & Groundwater process & -1.7 \\
6 & GW_REVAP & Groundwater process & 1.51 \\
7 & SURLAG & Surface runoff & -1.25 \\
8 & GWQMN & Soil moisture & 1.08 \\
9 & SOL_K(1) & Soil moisture & -0.83 \\
10 & SMTMP & Snowfall and snowmelt & -0.71 \\
\hline
\end{tabular}




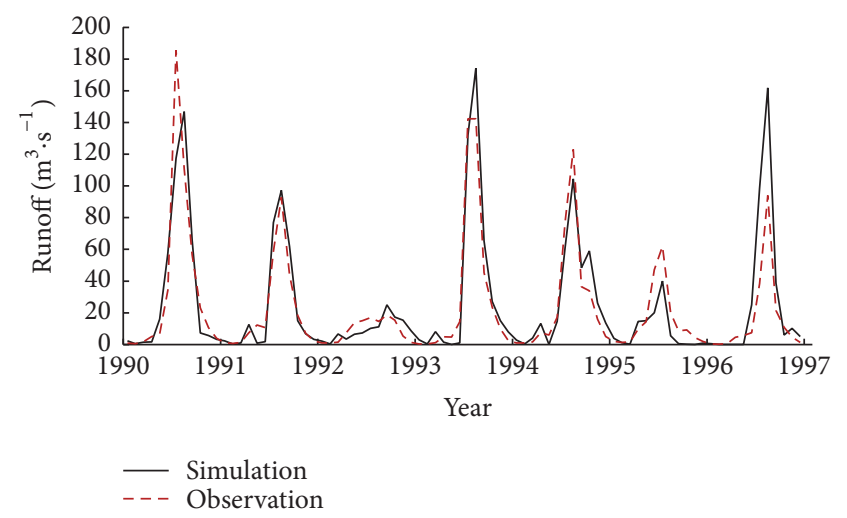

(a) Suolun

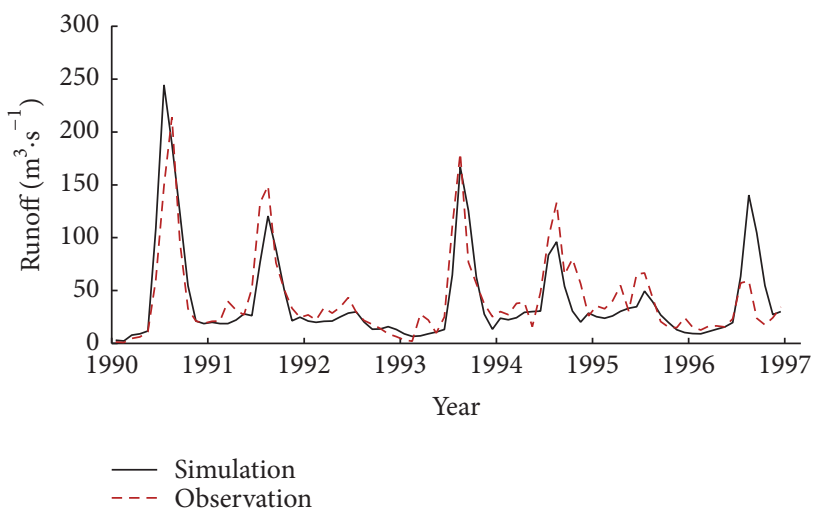

(c) Zhenxi

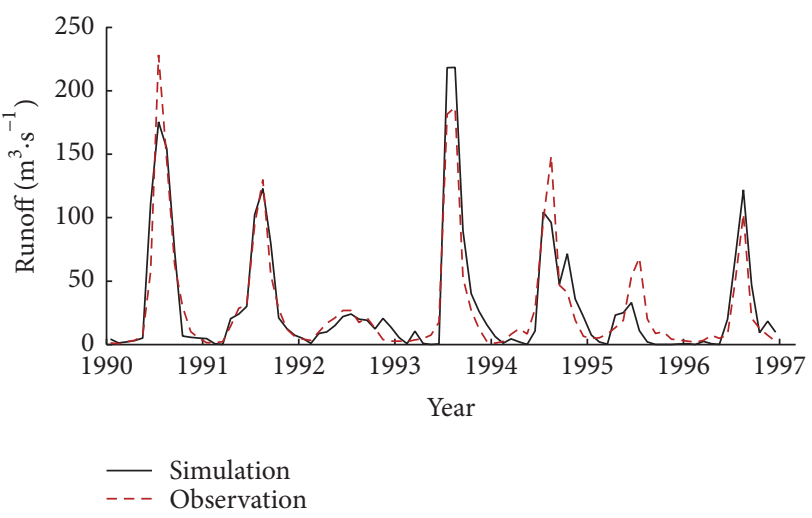

(b) Chaersen

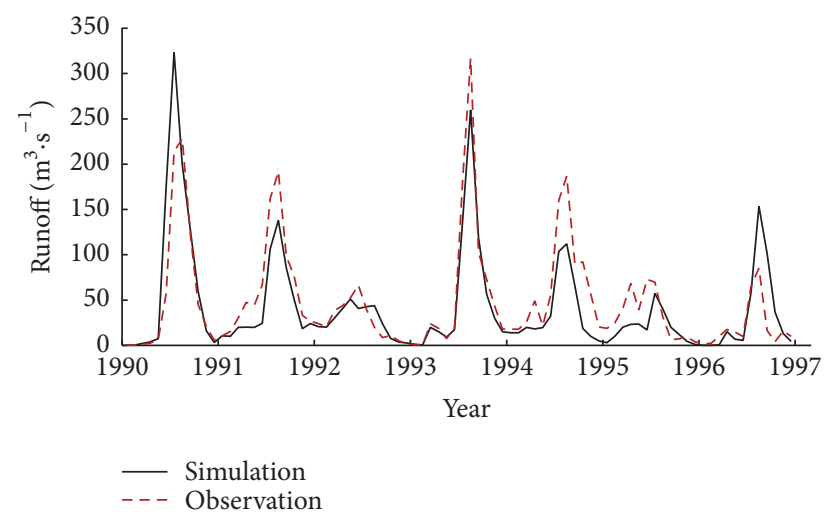

(d) Taonan

FIGURE 5: Comparison of the observed and best simulated discharges for the four main hydrometric stations located in the Taoer River basin during the calibration (1990-1993) and validation (1994-1996) periods.

$$
\mathrm{RE}=\frac{\sum_{i=1}^{n}\left(Q_{s i}-Q_{m i}\right)}{\sum_{i=1}^{n} Q_{m i}} \times 100 \%
$$

where $Q_{m i}$ is the measured flow rate, $\mathrm{m}^{3} / \mathrm{s} ; Q_{s i}$ is the analog flow rate, $\mathrm{m}^{3} / \mathrm{s} ; \overline{Q_{m}}$ is the average measured flow rate, $\mathrm{m}^{3} / \mathrm{s}$; $\overline{Q_{s}}$ is the average analog flow rate, $\mathrm{m}^{3} / \mathrm{s}$; and $n$ is the number of samples.

$E_{\mathrm{NS}}=1$ indicates that the analog value and measured value are equal. $E_{\mathrm{NS}}$ is usually between 0 and 1; a higher $E_{\mathrm{NS}}$ value indicates a higher coincidence of the simulated and measured values. If $E_{\mathrm{NS}}$ is negative, then the credibility of the analog value is less than the measured average. A correlation coefficient $R^{2}$ value closer to 1 indicates that the analog value and measured value trends are more synchronized; that is, the analog is better. The relative error RE reflects the deviation degree between the overall simulated and measured values. An RE closer to 0 indicates a greater match between the simulated and measured values. For runoff simulations of large basins over long time periods, a combination of these three evaluation criteria is used; when $E_{\mathrm{NS}}>0.50, R^{2}>0.60$, and $\mathrm{RE}<25 \%$, the simulation result is excellent.

3.7. Analysis of the Simulation Results. Comparison of simulated and measured monthly runoff is shown in Figure 5; the results of the simulation evaluation are shown in Table 6 .
As seen from Table 3, the simulation results are fairly accurate at the Solun and Chaersen stations, which are in the upstream region of the river. In the calibration and verification periods, the efficiency coefficients $E_{\mathrm{NS}}$ were greater than 0.70 ; the correlation coefficients $R^{2}$ were also greater than 0.70; and the relative errors RE were less than $20 \%$. In general, the simulation accuracy is high. At the Zhenxi and Taonan stations, which are also in the upstream region, the simulation results of the calibration period are acceptable. However, in the verification period, the correlation coefficient $R^{2}$ of the Zhenxi station was $29 \%$, and the efficiency coefficient $E_{\mathrm{NS}}$ of the Taonan station was 0.42 . These values suggest relatively low accuracy. This result is mainly because the description of the surface runoff yield of the SWAT model is in relatively great detail, but the groundwater process is simply generalized, and the manner of simulating groundwater is one-dimensional and conceptual. Groundwater flow between the different subbasins is thus not considered. Exchange between shallow groundwater and deep groundwater is also lacking in terms of a dynamic description. Therefore, it is difficult to accurately describe the transformation process between the complex surface water and groundwater in the SWAT model [41]. The Taonan and Zhenxi stations are located in the middle and lower plains of the basins. The conversion mode between surface water and 
TABLE 6: Model performance assessment during the calibration and validation periods.

\begin{tabular}{|c|c|c|c|}
\hline Simulation period & $E_{\mathrm{NS}}$ & $\mathrm{RE}$ & $R^{2}$ \\
\hline \multicolumn{4}{|c|}{ Suolun } \\
\hline Calibration period (1990-1993) & 0.88 & $-5 \%$ & 0.88 \\
\hline Validation period (1994-1996) & 0.83 & $19 \%$ & 0.88 \\
\hline \multicolumn{4}{|c|}{ Chaersen } \\
\hline Calibration period (1990-1993) & 0.91 & $-9 \%$ & 0.92 \\
\hline Validation period (1994-1996) & 0.72 & $7 \%$ & 0.73 \\
\hline \multicolumn{4}{|c|}{ Zhenxi } \\
\hline Calibration period (1990-1993) & 0.77 & $3 \%$ & 0.81 \\
\hline Validation period (1994-1996) & 0.5 & $29 \%$ & 0.72 \\
\hline \multicolumn{4}{|c|}{ Taonan } \\
\hline Calibration period (1990-1993) & 0.81 & $7 \%$ & 0.75 \\
\hline Validation period (1994-1996) & 0.42 & $22 \%$ & 0.62 \\
\hline
\end{tabular}

groundwater is very complicated. The river recharges groundwater, while the SWAT model only considers the shallow groundwater undirectionally recharging the river. The model therefore has inaccurate assumptions that are inconsistent with observations. These inherent defects can lead to a certain degree of error in the SWAT model simulation of the Zhenxi and Taonan stations.

\section{Hydrological Response in the Assumed Future Climate Scenarios}

4.1. Future Climate Change. Climate change scenarios mainly consider temperature and precipitation changes. Previous studies have debates in the mechanism of its influence on the river basin. Wang $\mathrm{Ni}$ et al. [42] analyzed historical hydrological and meteorological data of the Taoer River basin between 1958 and 2006. The results show that the average temperature increases, and the general trend of precipitation in the basin is not significant. Jiang et al. [43] noted that the precipitation and temperature of the Taoer River basin showed a rising trend. Xiaofan et al. [44] predicted the future temperature and precipitation in the Songhua River basin (the Taoer River basin is in the Songhua River basin range) with ECHAM5/MPI-OM, which is provided by the Climate Change Center of the China Meteorological Administration and the German Max Planck Meteorological Research Institute, using IPCC SRES 3 emission scenarios (A2, A1B, and B1). The results show that, regardless of the scenario, there is a significant increase in the temperature, but the annual precipitation shows no obvious change. Lu et al. [45] used the Co-Kriging interpolation method to study the spatial distribution of temperature in the Songhua River basin and the linear trend estimation method and Mann Kendall rank correlation method to analyze the temporal variation of the regional temperature. The study showed that annual average temperature in the Songhua River basin significantly increased at a rate of 0.039 degrees per year, which is above the global and national rates.

Under climate change scenarios, to investigate the changes of Taoer River basin runoff, this paper imported the results of the IPCC fifth climate change assessment report for
TABLE 7: Future climate change scenarios.

\begin{tabular}{lccc}
\hline Decade & $2020 \mathrm{~s}$ & $2030 \mathrm{~s}$ & $2040 \mathrm{~s}$ \\
Temperature & $+1.17^{\circ} \mathrm{C}$ & $+1.56^{\circ} \mathrm{C}$ & $+1.95^{\circ} \mathrm{C}$ \\
Precipitation & $+3 \%$ & $+4 \%$ & $+5 \%$ \\
\hline
\end{tabular}

future climate prediction. Considering 1990-1996 as the base period, the change in temperature and precipitation over the next 10 years (2020s), 20 years (2030s), and 30 years (2040s) was modeled (Table 7 ). Climate change mainly considers two factors, that is, temperature and precipitation, and it is assumed that the monthly distribution of the input factors remains unchanged.

4.2. Hydrological Response Analyses of Future Climate Change. Based on the assumption of future climate change scenarios, the SWAT model was used to estimate runoff in the Taoer River basin on a monthly scale for the future periods. Table 8 lists the runoff in the reference and future periods. The results show that the average annual runoff in the basin is slightly increased over the baseline period (1990-1996) during the next thirty years. However, in the 2040s, the average annual flow is reduced compared with the 2030s. Overall, the average runoff of each station has a tendency of increase and then decrease. In summary, there is a close relationship between runoff and temperature, rainfall, and other climate factors in the Taoer River basin.

\section{Analysis of the Impact of Land Use Types on Water Resources}

\subsection{Runoff Contribution Coefficient Analysis of Different Land Use Types}

5.1.1. Land Use of the Basin Controlled by the Hydrological Stations. For each subbasin of a given hydrological station, the vegetation type is shown in Figure 6. As shown in the figure, regardless of each subbasin, cultivated land (AGRL), woodland (FRST), and grassland (PAST) are the main vegetation types. Suolun station and Chaerson station are located in the upper reaches of the Taoer River basin and 
TABLE 8: Results of simulated runoff under future climate change scenarios.

\begin{tabular}{lccccccc}
\hline Hydrological station & $\begin{array}{c}\text { Base period } \\
\text { Runoff } \\
\left(\mathrm{m}^{3} / \mathrm{s}\right)\end{array}$ & $\begin{array}{c}\text { Runoff } \\
\left(\mathrm{m}^{3} / \mathrm{s}\right)\end{array}$ & $\begin{array}{c}\text { Runoff } \\
\left(\mathrm{m}^{3} / \mathrm{s}\right)\end{array}$ & $\begin{array}{c}\text { Runoff } \\
\left(\mathrm{m}^{3} / \mathrm{s}\right)\end{array}$ & $\begin{array}{c}\text { Runoff } \\
\left(\mathrm{m}^{3} / \mathrm{s}\right)\end{array}$ & $\begin{array}{c}\text { 2030s } \\
\left(\mathrm{m}^{3} / \mathrm{s}\right)\end{array}$ & $\begin{array}{c}\text { Runoff } \\
\left(\mathrm{m}^{3} / \mathrm{s}\right)\end{array}$ \\
\hline Suolun & 22.60 & 23.12 & 0.53 & 23.26 & 0.67 & 23.03 \\
Chaersen & 29.65 & 30.40 & 0.76 & 30.62 & 0.97 & 30.22 & 0.44 \\
Zhenxi & 42.38 & 43.66 & 1.28 & 44.04 & 1.66 & 43.57 & 1.19 \\
Taonan & 48.69 & 50.28 & 1.59 & 50.80 & 2.12 & 50.73 \\
\hline
\end{tabular}
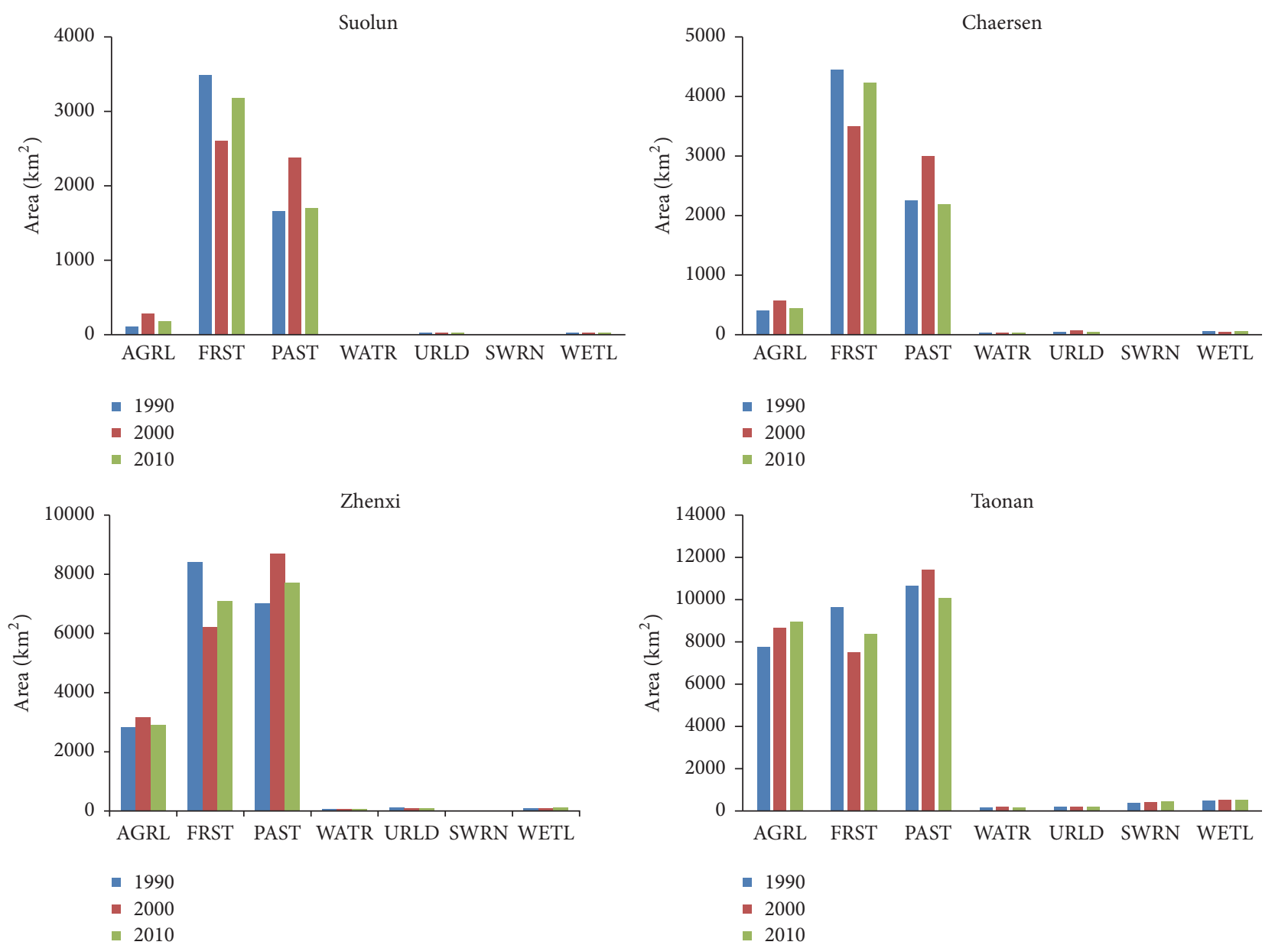

FIgURE 6: Land use of the Taoer River basin.

in mountainous areas, which are at high altitudes. The areas controlled by stations were $5273 \mathrm{~km}^{2}$ and $7182 \mathrm{~km}^{2}$. The area covered by cultivated land, woodland, and grassland accounts for more than $98 \%$ of the basin controlled by the Chaersen station. The Zhenxi and Taonan stations are located in the middle and lower reaches of the river basin, which is flat terrain at low altitude. The areas controlled by stations were $18702 \mathrm{~km}^{2}$ and $29154 \mathrm{~km}^{2}$. The area covered by cultivated land, woodland, and grassland accounts for more than $95 \%$ of the basin controlled by Taonan station.

5.1.2. Simulation Results of the SWAT Model for Different Land Use Types. Using the calibrated SWAT model, all parameters are kept constant, respectively, and the land use data (1990,
2000, and 2010) are incorporated. According to the model output, the Suolun station, the Chaersen station, the Zhenxi station, the Taonan station, and some other output results were analyzed. The runoff of each station is shown in Table 9.

5.1.3. Analysis of the Simulation Results. Different land use types have different effects on watershed runoff. To assess the three major land use types (AGRL, FRST, and PAST), this study calculates the runoff depth contribution coefficients using the multiobjective decision-making method in MATLAB. The results are shown in Table 10.

Analysis of the results shows that the contribution coefficients of the same land use type are different in the mountains area compared to the plains area. 
TABLE 9: Runoff in the Taoer river basin.

\begin{tabular}{lcccc}
\hline Runoff $\left(\mathrm{m}^{3} / \mathrm{s}\right)$ & Suolun & Chaersen & Zhenxi & Taonan \\
\hline 1990 & 26.08 & 33.61 & 47.49 & 34.73 \\
2000 & 23.69 & 30.52 & 36.16 & 34.68 \\
2010 & 24.92 & 31.55 & 41.69 \\
\hline
\end{tabular}

TABLE 10: The contribution coefficients of land use types to the river runoff depth.

\begin{tabular}{|c|c|c|c|c|}
\hline Contribution coefficient & Suolun & Chaersen & Zhenxi & Taonan \\
\hline AGRL & -0.0148 & -0.0054 & -0.0048 & -0.0043 \\
\hline FRST & 0.0203 & 0.0335 & 0.0045 & 0.0019 \\
\hline PAST & 0.0085 & 0.0251 & -0.0043 & -0.0024 \\
\hline
\end{tabular}

The contribution coefficients of arable land are all negative; that is, arable land has an inhibitory effect on runoff generation. The runoff decreased with increasing of cultivated area. However, in decreasing cultivated area, the runoff increased. In arable land, plowing makes the upper soil loose, which is conducive to water infiltration, thus inhibiting runoff.

The contribution coefficients of woodland are all positive; that is, woodland enhances runoff generation. As woodland is normally located in mountains or hilly areas, it is difficult for the rainfall to remain in these steep slope areas and the runoff can rapidly form. Furthermore, forested areas are generally unsuitable for farming, the land is barren, the vegetation coverage is low, and the litter and humus layers are small; these characteristics are not conducive to rainfall infiltration. Therefore, the formation of woodland played a facilitating role for runoff generation. The runoff increased with increasing woodland.

For grassland, the contribution coefficients are positive in basins controlled by the Soren and Chersen hydrological stations, while those in basins controlled by the Taonan and Zhenxi hydrological stations are negative. The main reasons are as follows: grasslands in the area controlled by Soren and Chersen station are located in mountainous regions where the rainfall infiltration is not significant; in the downstream plains area, lush grass is not conducive to water flow; and the grassland inhibits runoff generation, in which case the runoff decreased with increasing grassland area.

\subsection{Impacts of Land Use Change on Water Resource Analysis}

\subsubsection{Land Use of the Area between Chaersen and Taonan.} The Taoer River basin is located in arid and semiarid area, where water resource shortage is a pressing concern. Based on the impact analysis of land use type changes on runoff, the impact of land use type changes on water demand in the region between the Chaersen hydrological station and the Taonan hydrological station (Figure 7) was also studied. The area of this region is $10,400 \mathrm{~km}^{2}$, and the land use types are shown in Figure 8. Over the past 20 years, the area of arable land increased by $1103 \mathrm{~km}^{2}$, and grassland decreased by $1206 \mathrm{~km}^{2}$; areal changes of other land use types are less obvious.
5.2.2. Impacts of Land Use on Agricultural Water Demand. The water demand of different land use types (such as arable land, grassland, and woodland) is different. In the study area the areal changes of land use types were not obvious, except for arable land and grassland. Therefore, arable land and grassland were the two types that have been studied in terms of the effects of land use change on agricultural water demand.

As the water demands of different farming types are not the same, the water quotas of agricultural water demand of the respective arable land areas were calculated. According to the results of actual investigation and a remote sensing data analysis, paddy acreage accounts for $8.1 \%$ of the total arable land, and dry land accounts for the remaining $91.9 \%$. The irrigation quota of the average paddy is $15000 \mathrm{~m}^{3} / \mathrm{hm}^{2}$, and the average irrigation quota for dry land is $4125 \mathrm{~m}^{3} / \mathrm{hm}^{2}$. Amount of agricultural water demand increased by 552 million $\mathrm{m}^{3}$ over the last 20 years. The growth of grass does not generally require irrigation. Because grassland does not need irrigation, the water demand change of grassland was not calculated in this study. Therefore, with the increase of the cultivated area, the agricultural water demand also showed an increasing trend.

Furthermore, not only the agricultural water demand but also the industrial water demand and domestic water demand have increased, with the gradual increase of socioeconomic development and living standards. Thus, the gap between supply and demand of water resources will be increasingly prominent.

\section{Discussion}

The simulation, calibration, and validation results of the SWAT model applied to the Taoer River basin show that the SWAT model has strong applicability; this model can be used to simulate the monthly runoff process in this basin. The simulation accuracy of the Solon and Chaerson stations in the upstream region is much higher than that at other stations. Due to the limitations of rainfall data and generalized simple simulation results of groundwater, there were some errors in the simulation. These errors are within the acceptable range for the study purpose of assessing the long-term effects [24]. 


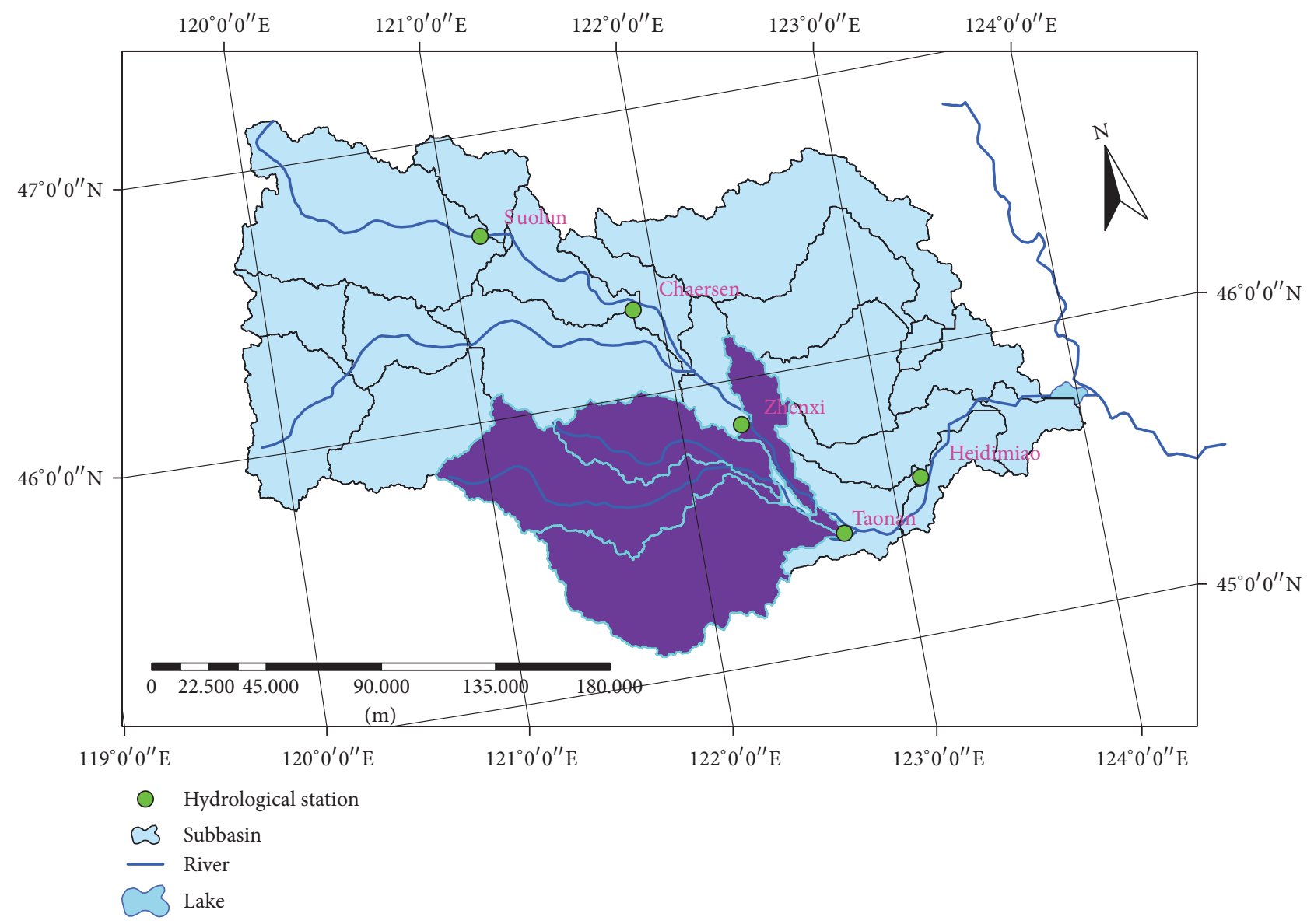

Figure 7: Area of the Chaersen and Taonan stations.

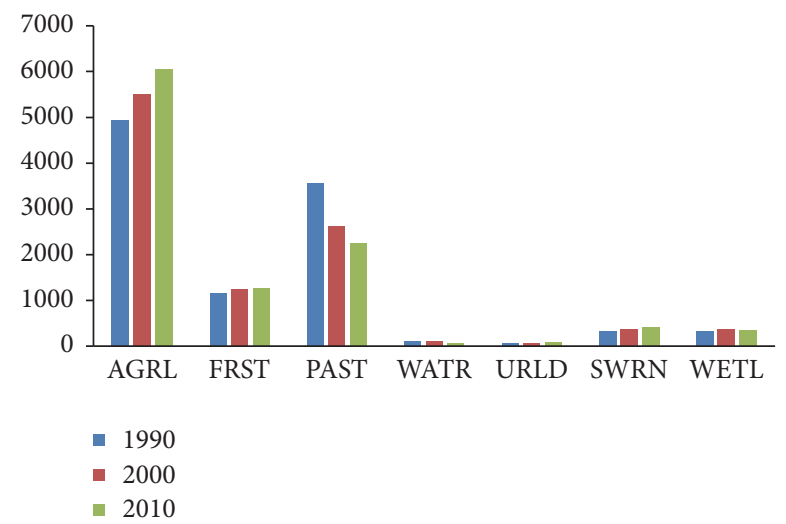

Figure 8: Land use of the Chaersen and Taonan stations.

At present, emissions scenarios (Special Report on Emissions Scenarios, SRES) and a number of climate models are used in future climate predictions. However, the simulation results of different climate models are not the same, and the uncertainty of future climate forecasting is increased [46]. In this study, the future climate change assumption is based on the study results of local climate predictions. As the future climate is uncertain, many other factors will affect hydrology and water resources, in addition to rainfall and temperature.
Thus, the predictable results are based on the assumption of the ideal situation.

Research on the relationship between land use and runoff has been extensively conducted. As the relationship between land use and water resources is very complex, topography, soil type, and crop management all impact runoff, and the impact of land use types on runoff differs from region to region [47]. The results of this study can be applied only when the geographical and climatic conditions are similar to this area.

This paper studied the impacts of climate change and land use changes on runoff, and a combined comprehensive analysis will be performed in future studies.

\section{Conclusions}

Based on the assumption of future climate scenarios, the change on the predicted runoff of the Taoer River compared with that in the base period is not obvious. It increases slightly in the 2020s and 2030s but decreases in the 2040s. The relevant authorities should consider that climate change will affect water resource changes, and the use of local engineering measures and nonengineering measures should be employed to minimize the adverse impacts of water resources on social and economic development. 
The land use types in the TRB are mainly farmland, woodland, and grassland. The SWAT model and multiobjective decision-making method were used to quantitatively analyze the contribution coefficients of these three major land use types to the runoff. The results showed that, in the $\mathrm{TRB}$, the contribution coefficient of farmland is negative; that is, farmland inhibits runoff; the woodland contribution coefficient is positive; that is, woodland enhances runoff, while, for grassland, in the upper reaches of the mountainous area, grassland plays a catalytic role in runoff, whereas grassland inhibits runoff in the downstream plains. In the past 20 years, the land use type changes caused an increase in the agricultural water demand, which has intensified the disparity between the water supply and demand.

To fill the gap between the supply and demand of water resources and to ensure sustainable and stable development of the local economy, authorities should address this issue through multiple measures. Construction of rivers and lakes has been proposed, where the Yueliangpao reservoir at the end of Taoer River will be used to connect the Nenjiang River to the Taoer River.

\section{Conflicts of Interest}

The authors declare that there are no conflicts of interest regarding the publication of this paper.

\section{Acknowledgments}

This research is supported by the Natural Sciences Foundation of China $(51679026,51209030)$ and the National Key Research and Development Program of China (2016YFC0400903).

\section{References}

[1] T. G. Huntington, "Evidence for intensification of the global water cycle: review and synthesis," Journal of Hydrology, vol. 319, no. 1-4, pp. 83-95, 2006.

[2] IPCC, Climate Change 2014: Synthesis Report. Contribution of Working Groups I, II and III to the Fifth Assessment Report of the Intergovernmental Panel on Climate Change [Core Writing Team, R.K. Pachauri and L.A. Meyer (eds.)], IPCC, Geneva, Switzerland, 2014.

[3] Core Writing Team, R. K. Pachauri, and L. A. Meyer, Eds., IPCC Climate Change 2014: Synthesis Report Summary for Policymakers. Contribution of Working Groups I, II and III to the Fifth Assessment Report of the Intergovernmental Panel on Climate Change, IPCC, Geneva, Switzerland, 2014.

[4] S. Yongping and W. Guoya, "Key findings and assessment results of IPCC WGI fifth assessment report," Journal of Glaciology and Geocryology, vol. 35, no. 5, pp. 1068-1076, 2013.

[5] W. W. Immerzeel, "Historical trends and future predictions of climate variability in the Brahmaputra basin," International Journal of Climatology, vol. 28, no. 2, pp. 243-254, 2008.

[6] D. Labat, Y. Goddéris, J. L. Probst, and J. L. Guyot, "Evidence for global runoff increase related to climate warming," Advances in Water Resources, vol. 27, no. 6, pp. 631-642, 2004.

[7] L. Fengping, Z. Guangxin, and D. Liqin, "Studies for impact of climate change on hydrology and water resources," Scientia Geographica Sinica, vol. 33, no. 4, pp. 457-464, 2013.
[8] L. I. U. Zhi-juan, Y. Xiao-guang, W. Wen-feng, L. I. Ke-nan, and Z. Xiao-yu, "Characteristics of agricultural climate resources in three provinces of northeast china under global climate change," Chinese Journal of Applied Ecology, vol. 20, no. 9, pp. 2199-2206, 2009.

[9] M. S. Pervez and G. M. Henebry, "Assessing the impacts of climate and land use and land cover change on the freshwater availability in the Brahmaputra River basin," Journal of Hydrology: Regional Studies, vol. 3, pp. 285-311, 2015.

[10] H. Memarian, M. Tajbakhsh, and S. K. Balasundram, "Application of swat for impact assessment of land use/cover change and best management practices: a review," International Journal of Advancement in Earth and Environmental Sciences, vol. 1, no. 1, pp. 36-40, 2013.

[11] J. Liu, W. Kuang, Z. Zhang et al., "Spatiotemporal characteristics, patterns, and causes of land-use changes in China since the late 1980s," Journal of Geographical Sciences, vol. 24, no. 2, pp. 195-210, 2014.

[12] L. Yu, Z. Chi, Z. Huicheng, and S. Bicheng, "SWAT model of land use change on runoff research applications," in Chinese Hydraulic Engineering Society China Raw Water Forum Album, p. 4, Chinese Hydraulic Engineering Society, Beijing, China, 2010.

[13] C. Junfeng and L. Xiubin, "Simulation of hydrological response to land-cover changes," Chinese Journal of Applied Ecology, vol. 5, pp. 833-836, 2004.

[14] J. T. Guo, Z. Q. Zhang, S. P. Wang, P. Strauss, and A. K. Yao, "Appling SWAT model to explore the impact of changes in land use and climate on the streamflow in a watershed of Northern China," Shengtai Xuebao/ Acta Ecologica Sinica, vol. 34, no. 6, pp. 1559-1567, 2014.

[15] R. DeFries and K. N. Eshleman, "Land-use change and hydrologic processes: a major focus for the future," Hydrological Processes, vol. 18, no. 11, pp. 2183-2186, 2004.

[16] B. F. W. Croke, W. S. Merritt, and A. J. Jakeman, "A dynamic model for predicting hydrologic response to land cover changes in gauged and ungauged catchments," Journal of Hydrology, vol. 291, no. 1-2, pp. 115-131, 2004.

[17] A. A. Romanowicz, M. Vanclooster, M. Rounsevell, and I. La Junesse, "Sensitivity of the SWAT model to the soil and land use data parametrisation: a case study in the Thyle catchment, Belgium," Ecological Modelling, vol. 187, no. 1, pp. 27-39, 2005.

[18] J. E. Chaves, C. Neill, S. Germer, S. G. Neto, A. V. Krusche, and H. Elsenbeer, "Land management impacts on runoff sources in small Amazon watersheds," Hydrological Processes, vol. 22, no. 12, pp. 1766-1775, 2008.

[19] Y. Wu, S. Liu, W. Yan et al., "Climate change and consequences on the water cycle in the humid Xiangjiang River Basin, China," Stochastic Environmental Research and Risk Assessment, vol. 30, no. 1, pp. 225-235, 2016.

[20] L. Kou, J. Liu, H. Zhang, and Q. Zhou, "Hydrological response to climate change in taoer river basin based on SWAT model," Water Resources and Power, vol. 2, no. 34, pp. 12-16, 2016.

[21] S. Kumar, V. Merwade, and B. C. Pijanowski, "Future water resource scenarios for USA: effects of land use/cover change, climate change and human disturbance," in Proceedings of the AGU Fall Meeting, AGU Fall Meeting Abstracts, 2010.

[22] L.-P. Zhang, L.-L. Qin, Z.-F. Hu, and S.-D. Zeng, "Simulated hydrologic responses to climate change of water source area in the Middle Route of South-to-North Water Transfer Project," Journal of Hydraulic Engineering, vol. 41, no. 11, pp. 1261-1271, 2010. 
[23] Z. Xu, F. Zhao, and J. Li, "Response of streamflow to climate change in the headwater catchment of the Yellow River basin," Quaternary International, vol. 208, no. 1-2, pp. 62-75, 2009.

[24] Y. Wu, S. Liu, and A. L. Gallant, "Predicting impacts of increased $\mathrm{CO}_{2}$ and climate change on the water cycle and water quality in the semiarid James River Basin of the Midwestern USA," Science of the Total Environment, vol. 430, pp. 150-160, 2012.

[25] Y. Wu, S. Liu, and O. I. Abdul-Aziz, "Hydrological effects of the increased $\mathrm{CO}_{2}$ and climate change in the Upper Mississippi River Basin using a modified SWAT,' Climatic Change, vol. 110, no. 3-4, pp. 977-1003, 2012.

[26] D. L. Ficklin, Y. Luo, E. Luedeling, S. E. Gatzke, and M. Zhang, "Sensitivity of agricultural runoff loads to rising levels of $\mathrm{CO}_{2}$ and climate change in the San Joaquin Valley watershed of California," Environmental Pollution, vol. 158, no. 1, pp. 223-234, 2010.

[27] Y. Panagopoulos, P. W. Gassman, R. W. Arritt et al., "Impacts of climate change on hydrology, water quality and crop productivity in the Ohio-Tennessee River Basin," International Journal of Agricultural \& Biological Engineering, vol. 8, no. 3, pp. 1-18, 2015.

[28] D. L. Ficklin, Y. Luo, E. Luedeling, and M. Zhang, "Climate change sensitivity assessment of a highly agricultural watershed using SWAT," Journal of Hydrology, vol. 374, no. 1-2, pp. 16-29, 2009.

[29] X. Wang, Z.-L. Zhang, and J.-C. Ning, "Runoff response to land use change in Baimahe basin of China based on SWAT model," Chinese Journal of Ecology, vol. 32, no. 1, pp. 186-194, 2013.

[30] L. Chengzhen, C. Xiaoxia, K. Qinghui, F. Peng, and D. Yuanfang, "Application of SWAT model in surface runoff simulation of Taoer river," Water Resources \& Hydropower of Northeast China, vol. 6, pp. 35-72, 2012.

[31] X.-R. Yin, G.-X. Zhang, F. Yang, and B. Xu, "Distributed hydrological modeling in semi-arid region in Northeast China: a case study in the Taoer River basin," Journal of Jilin University (Earth Science Edition), vol. 41, no. 1, pp. 137-144, 2011.

[32] J. Liu, L. Kou, and Q. Zhou, "Hydrological responses of climate and land use/cover changes in Tao'er River Basin based on the SWAT model," in Proceedings of the AGU Fall Meeting, 2015.

[33] Z. Liping, C. Xiaofeng, Z. Zhipeng, and H. Zhifang, "Progress in study of climate change impacts on hydrology and water resources," Progress in Geography, vol. 3, pp. 60-67, 2008.

[34] L. Fengfping, Z. Guangxin, and D. Liqin, "Study on impact of climate change on hydrology and water resources," Scientia Geographica Sinica, vol. 04, pp. 457-464, 2013.

[35] W. Zhonggen, L. Changming, and H. Youbo, "The theory of SWAT model and its application in Heihe Basin," Progress in Geography, vol. 22, no. 1, pp. 79-86, 2003.

[36] P. Jingpeng, C. Changchun, Y. Xuhong, Y. Yixing, and D. Jinkang, "SWAT model application: state-of-the-art review," Research of Soil and Water Conservation, vol. 3, pp. 31-35, 2007.

[37] Z. Yi, W. Wenshou, and C. Caixia, "Water resource carrying capacity in Yanqi Basin based on multi-objective analysis," China Population Resources and Environment, vol. 20, no. 11, pp. 60-65, 2010.

[38] P. Jinghu, D. Peiji, and Z. Ruifeng, "Research on optimization allocation model of land use structure based on LP-MCDM-CA model in Tianshui City," Journal of Mountain Science, vol. 28, no. 4, pp. 407-414, 2010.

[39] Z. Yuqing, C. Changchun, Y. X. Hong, Y. Y. Xing, and J. Kang, "Application of SWAT model based on SUFI-2 algorithm to runoff simulation in Xiushui Basin," Water Resources and Power, vol. 9, pp. 24-28, 2013.
[40] K. C. Abbaspour, C. A. Johnson, and M. T. van Genuchten, "Estimating uncertain flow and transport parameters using a sequential uncertainty fitting procedure," Vadose Zone Journal, vol. 3, no. 4, pp. 1340-1352, 2004.

[41] Z. Hui, "SWAT model and its application research," in Progress in Geography, vol. 05, pp. 123-132, 2005.

[42] Y. R. Wang Ni, H. Lin, and W. Yong, “Taoer River Basin Hydro meteorological trends elements analysis," in Northeast Water Conservancy and Hydropower, vol. 01, pp. 45-47, 2012.

[43] D.-J. Jiang, L.-J. Li, X.-Y. Hou et al., "Variations in the hydrological cycle components and their influencing factors in the middle and upper reaches of Tao'erhe River Basin," Geographical Research, vol. 28, no. 1, pp. 55-64, 2009.

[44] Z. Xiaofan, Qiaoping, S. Buda, and L. Yulian, "Change and projection of climate in the Songhua River Basin," Advances in Climate Change, vol. 4, pp. 215-219, 2009.

[45] Z. Lu, Z. Xia, L. Yu, and J. Wang, "Characteristics of spatiotemporal variation of temperature in Songhua River Basin from 1960 to 2010," Journal of Hohai University, vol. 40, no. 6, pp. 629635, 2012.

[46] Z. Liping, Q. Linlin, and H. Zhifang, "Response had thought Dong water resource area of climate change the hydrological cycle," Journal of Hydraulic Engineering, vol. 11, pp. 1261-1271, 2010.

[47] L. Wenhua, H. Tao, and Y. Li Yun, "A summary and perspective of forest vegetation impacts on water yield," Natural Resources, vol. 05 , pp. $398-406,2001$. 

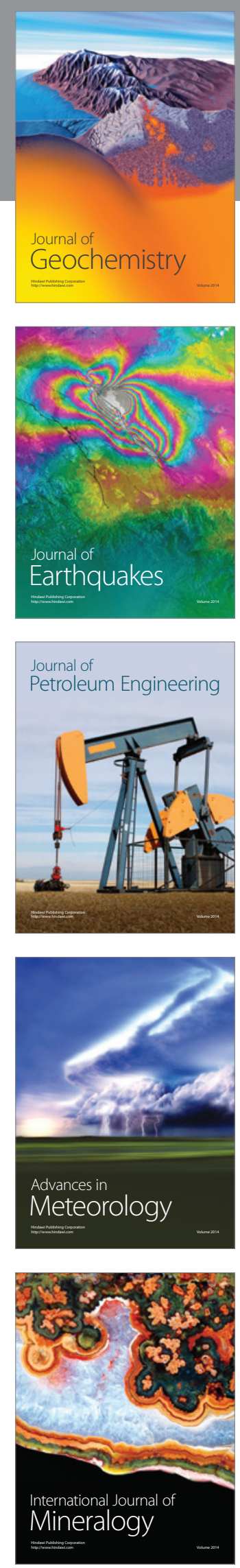
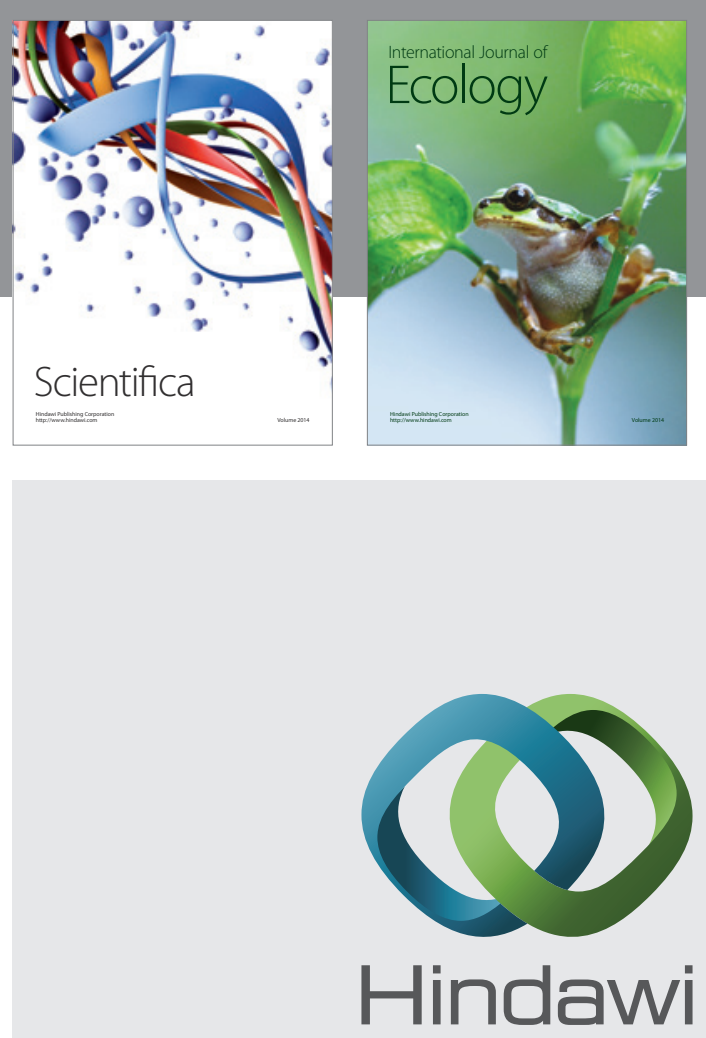

Submit your manuscripts at

https://www.hindawi.com
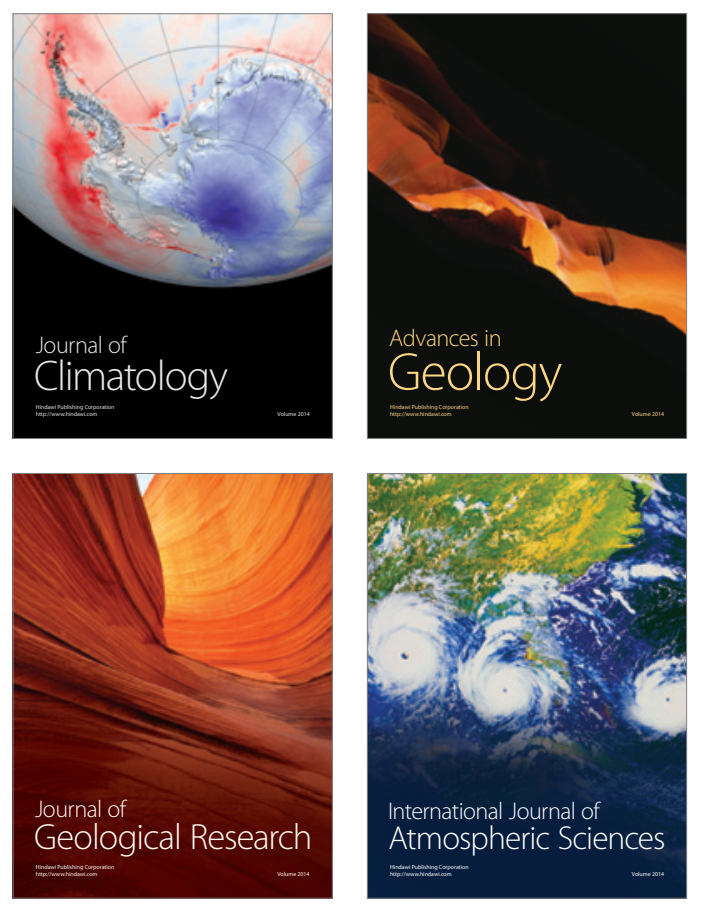

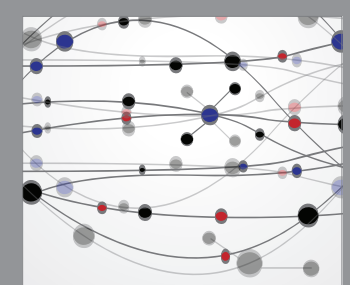

The Scientific

\section{World Journal}
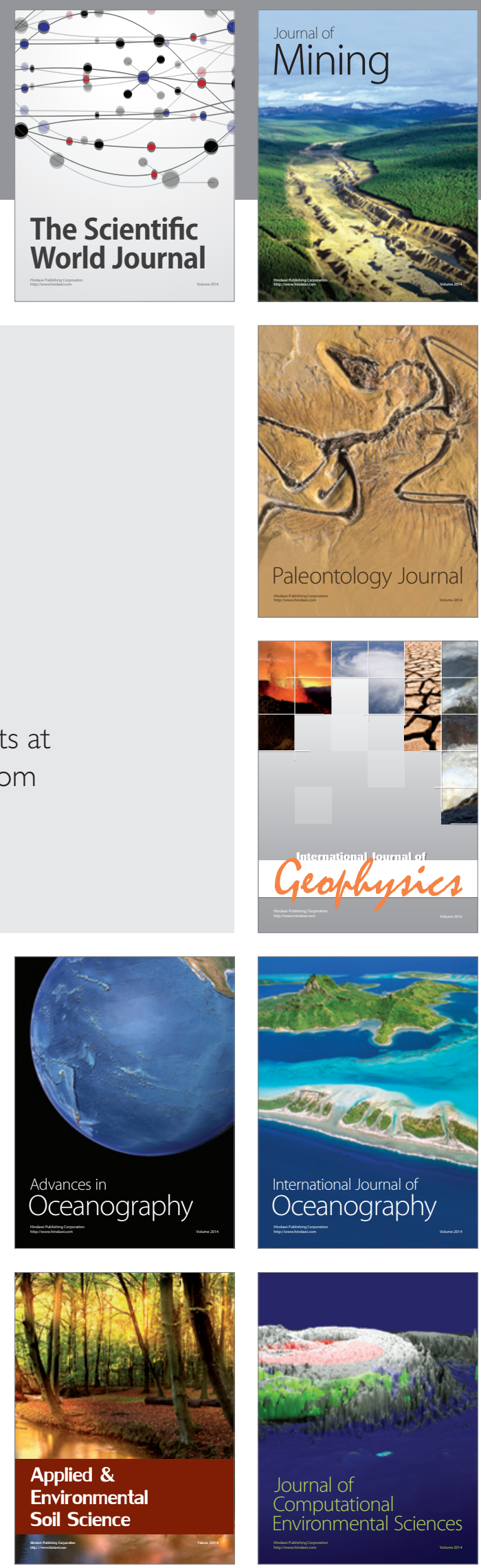